\title{
Trace metal distributions in the sediments from river-reservoir systems: case of the Congo River and Lake Ma Vallée, Kinshasa (Democratic Republic of Congo)
}

\author{
Paola M. Mwanamoki • Naresh Devarajan • Birane Niane • Patience Ngelinkoto • \\ Florian Thevenon • José W. Nlandu • Pius T. Mpiana • Kandasamy Prabakar • \\ Josué I. Mubedi • Christophe G. Kabele • Walter Wildi • John Poté
}

Received: 10 January 2014 / Accepted: 23 July 2014 /Published online: 6 August 2014

(C) Springer-Verlag Berlin Heidelberg 2014

\begin{abstract}
The contamination of drinking water resources by toxic metals is a major problem in many parts of the world, particularly in dense populated areas of developing countries that lack wastewater treatment facilities. The present study characterizes the recent evolution with time of some contaminants deposited in the Congo River and Lake Ma Vallée, both located in the vicinity of the large city of Kinshasa, capital of Democratic Republic of Congo (DRC). Physicochemical parameters including grain size distribution, organic matter and trace element concentrations were measured in sediment cores sampled from Congo River $(n=3)$ and Lake Ma Vallée $(n=2)$. The maximum concentration of trace elements in sediment profiles was found in the samples from the sites of Pool Malebo, with the values of 107.2, 111.7,
\end{abstract}

Responsible editor: Céline Guéguen

John Pote is associate professor for the collaboration between Forel Institute (University of Geneva) and two Universities of Kinshasa (UPN and UNIKIN).

P. M. Mwanamoki

Section Nutrition Diététique, Institut Supérieur des Techniques

Médicales/Kinshasa, B.P. 774, Kinshasa XI, Democratic Republic of

Congo

N. Devarajan $\cdot$ B. Niane $\cdot$ F. Thevenon $\cdot$ W. Wildi $\cdot$ J. Poté $(\triangle)$ Faculty of Science, Forel Institute and Institute of Environmental Sciences, University of Geneva, CP 416, 1290 Versoix, Switzerland e-mail: john.pote@unige.ch

N. Devarajan $\cdot$ K. Prabakar

Postgraduate and Research Department of Zoology, Jamal Mohamed

College, Tiruchirappalli 620020, Tamil Nadu, India

P. Ngelinkoto $\cdot$ J. I. Mubedi $\cdot$ J. Poté

Université Pédagogique Nationale (UPN), Croisement Route de

Matadi et Avenue de la Libération, Quartier Binza/UPN, B.P. 8815,

Kinshasa, Democratic Republic of Congo
88.6, 39.3, 15.4, 6.1 and $4.7 \mathrm{mg} \mathrm{kg}^{-1}$ for $\mathrm{Cr}, \mathrm{Ni}, \mathrm{Zn}, \mathrm{Cu}$, $\mathrm{Pb}$, As and $\mathrm{Hg}$, respectively. This site, which is characterized by intense human activities, is especially well known for the construction of numerous boats that are used for regular navigation on Congo River. Concerning Lake $\mathrm{Ma}$ Vallée, the concentration of all metals are generally low, with maximum values of 26.3, 53.6, 16.1, 15.3, 6.5 and $1.8 \mathrm{mg} \mathrm{kg}^{-1}$ for $\mathrm{Cr}, \mathrm{Ni}, \mathrm{Zn}, \mathrm{Cu}, \mathrm{Pb}$ and $\mathrm{As}$, respectively. However, the comparison of the metal profiles retrieved from the different sampled cores also reveals specific variations. The results of this study point out the sediment pollution by toxic metals in the Congo River Basin. This research presents useful tools for the evaluation of sediment contamination of river-reservoir systems.

\section{J. W. Nlandu}

Commissariat général à l'énergie atomique, Département de Physique des sols et Hydrologie, B.P.868, Kinshasa XI, Democratic Republic of Congo

P. T. Mpiana $\cdot$ C. G. Kabele • J. Poté

Faculty of Science, Department of Chemistry, University of Kinshasa (UNIKIN), B.P. 190, Kinshasa XI, Democratic Republic of Congo

Present Address:

F. Thevenon

IUCN Global Marine and Polar Programme, Rue Mauverney 28, 1196 Gland, Switzerland 
Keywords Toxic metals $\cdot$ Contamination $\cdot$ Sediments · Anthropogenic activities · Urbanisation · Congo River Basin

\section{Introduction}

The contamination of rivers, lakes and water reservoirs by different types of contaminants including heavy metals, persistent organic pollutants, pharmaceutical drugs and pathogenic organisms constitutes a major environmental concern in many parts of the world and a major threat for the world's freshwater resources (Vörösmarty et al. 2010; Haller et al. 2011; Thevenon et al. 2011a, b; 2013). The assessment of the pollution of aquatic systems used as drinking water supply or for recreational activities is usually monitored by chemical measurements of water or sediment quality (e.g. Redeker et al. 2004; Thevenon and Poté 2012; Hu et al. 2013). However, the composition of the surface waters (lakes and rivers) can rapidly and greatly fluctuate during the year, for instance, following an important rainfall event or short-term anthropogenic pollution (e.g. spreading of manure, industrial discharge and mining activity). By contrast, the chemical composition of sediments reflects the composition of the water quality on a longer period (e.g. season or year), and this approach is therefore more representative of the real water quality. Hence, the sediments represent an important environmental compartment for the assessment of the pollution in river-reservoir systems, where the deposits formed by a complex mixture of organic and inorganic compounds can additionally accumulate contaminants and pathogenic organisms at concentrations ten to 1,000 times higher than the overlying water (Davies et al. 1995; Poté et al. 2008; Haller et al. 2009). Therefore, the measurement of pollutants in the overlying waters is not conclusive due to fluctuations of water discharge, changing concentration in suspended matter and low resident time, whereas the analysis of river sediments is a useful method to assess metal pollution (Förstner and Wittmann 1979; Schwarzenbach et al. 2006; Varol 2011). Moreover, polluted sediments represent a potential source of contamination for freshwater organisms (Kang et al. 2000; Ngelinkoto et al. 2014). Therefore, in the context of anthropogenic-triggered aquatic environmental changes, sedimentary archives provide an excellent opportunity to reconstruct the level, evolution with time and patterns of pollutants, namely, toxic metals, organic nutrients, pesticides and persistent organic pollutants (POPs) emitted to aquatic systems over the last decades or even centuries (Thevenon et al. 2013).

In developing countries, the deterioration of the quality of crucial freshwater mainly results from the important discharge of untreated industrial effluents, agricultural and urban activities, mining activities, uncontrolled urban landfills, improperly processed hospital effluents and domestic wastewater which in turn pose tremendous effects and health risk to consumers (Brayner et al. 2001; Kambole 2003; Key et al. 2004; Atibu et al. 2013). In highly populated and industrialized areas, the urban river systems may receive various types of toxic contaminants, including suspended organic loads from soil erosion due to rainwater runoff, urban and hospital effluents and leachates from the numerous waste dumps located along the rivers (Gnandi et al. 2011; Mubedi et al. 2013).

In the vicinity of large towns of DRC, as well as in mining regions, the Congo River and its tributaries receive large amount of untreated industrial effluents as well as urban domestic solid wastes from various sources. As a consequence, water and sediments of the Congo River-reservoir system get contaminated with heavy metals and other hazardous pollutants (Banza et al. 2009; Atibu et al. 2013; Mees et al. 2013).

The Congo River is the most important river of DRC, with an overall length of $4,700 \mathrm{~km}$ and a drainage basin covering $4,014,500 \mathrm{~km}^{2}$. The river basin is the second largest drainage basin in the world after the Amazon and has a great economic importance (Dupré et al. 1996). Due to the degradation of the main road network and to the rare railways in the country, the Congo River constitutes the principal transportation artery of supply for goods and services between the large towns of DRC such as Kinshasa (ten million inhabitants), Kisangani (nearly 700,000 inhabitants), Bumba (about 110,000 inhabitants), Mbandaka (about 345,000 inhabitants) and Matadi (about 310,000 inhabitants). Consequently, there is intensive river navigation along the Congo River. In the vicinity of the large towns, the river and its tributaries receive untreated industrial and hospital effluents, urban storm water runoff and urban liquid and solid waste. Few studies have been performed to assess the water and sediment quality in the Congo River Basin (Dupré et al. 1996; Verhaert et al. 2013). To our knowledge, very little data are available about the heavy metal accumulation in sediments of Congo River and in the vicinity of the city of Kinshasa, while there is no information regarding the water and sediment quality of Lake Ma Vallée, a small artificial reservoir lake surrounded by primitive equatorial forest. The lake is protected and well known as a place of leisure, sports and relaxation by the population from Kinshasa city.

In the present study, we aim to evaluate the level of pollution of these two river-reservoir systems by determining the concentration of organic matter and trace 
elements (including toxic metals) in sediments. In order to achieve this objective, five short sediment cores were sampled from the Congo River in the vicinity of Kinshasa and two short sediment cores from Lake Ma Vallée (entry and exist of the lake). Analysis of the sediment samples was performed for grain size distribution, organic matter and trace elements including $\mathrm{Ti}, \mathrm{V}$, $\mathrm{Cr}, \mathrm{Mn}, \mathrm{Fe}, \mathrm{Co}, \mathrm{Ni}, \mathrm{Cu}, \mathrm{Zn}, \mathrm{Ga}, \mathrm{As}, \mathrm{Ag}, \mathrm{Cd}, \mathrm{Sn}$ and $\mathrm{Pb}$.

\section{Materials and methods}

Study sites and sampling procedure

Congo River Three sites have been chosen to collect sediment cores in the vicinity of Kinshasa (Fig. 1): (1) The area of Maluku ( $n=2$, Ma: MaA and MaB, about $60 \mathrm{~m}$ between $\mathrm{MaA}$ and $\mathrm{MaB}$ ) is located in the upstream inlet of pool Malebo, about $80 \mathrm{~km}$ east of the city Kinshasa; (2) The area of pool Malebo, Mongole site $(n=2$, Mo: MoA and MoB, about $50 \mathrm{~m}$ between MoA and MoB). This river pool is about $35 \mathrm{~km}$ in length and $23 \mathrm{~km}$ in width, with a surface of $500 \mathrm{~km}^{2}$ ; (3) The Chanic area $(\mathrm{CH}, n=1)$ is located at Kinsuka, downstream of pool Malebo, downstream of the industrial site of "Chantier naval du Groupe Chanimetal".

Lake Ma Vallée Two sediment cores were sampled at the entry (LMVaE) and outlet (LMVaS) of the lake (Fig. 1). The coordinates of all sampling sites for both CRB and LMV are reported in Table 1.

In June 2013, about 30- to 35-cm-long sediment cores were collected at about $3-\mathrm{m}$ water depth from all sites using local canoes (Fig. 2). The cores were transported to the laboratory of the Pedagogic National University (Kinshasa), opened and sliced into $3-\mathrm{cm}-$ thick sections. The sediment samples were frozen, freeze-dried and grounded into a fine homogenized powder for further chemical analysis. After this preliminary treatment, the samples were transported to Institute F.A. Forel, University of Geneva (Switzerland) for various analyses. Samples were collected in triplicates, and the sampling distance between each replicate was about $2 \mathrm{~m}$.

Sediment grain size, organic matter and total phosphorous analysis

The particle grain size was measured with a laser Coulter ${ }^{\circledR}$ LS-100 diffractometer (Beckman Coulter, Fullerton, CA, USA), following 5-min ultrasonic dispersal in deionized water according to the method described by Loizeau et al. (1994). The sedimentary organic matter content was estimated from loss on ignition at $550{ }^{\circ} \mathrm{C}$ for $1 \mathrm{~h}$ in a Salvis oven (AG Emmenbrücke, Luzern, Switzerland). The total phosphorus (TP) concentration was measured with a spectrophotometer (Helios Gamma UV-vis Thermo Electroporation, Thermo Scientific,

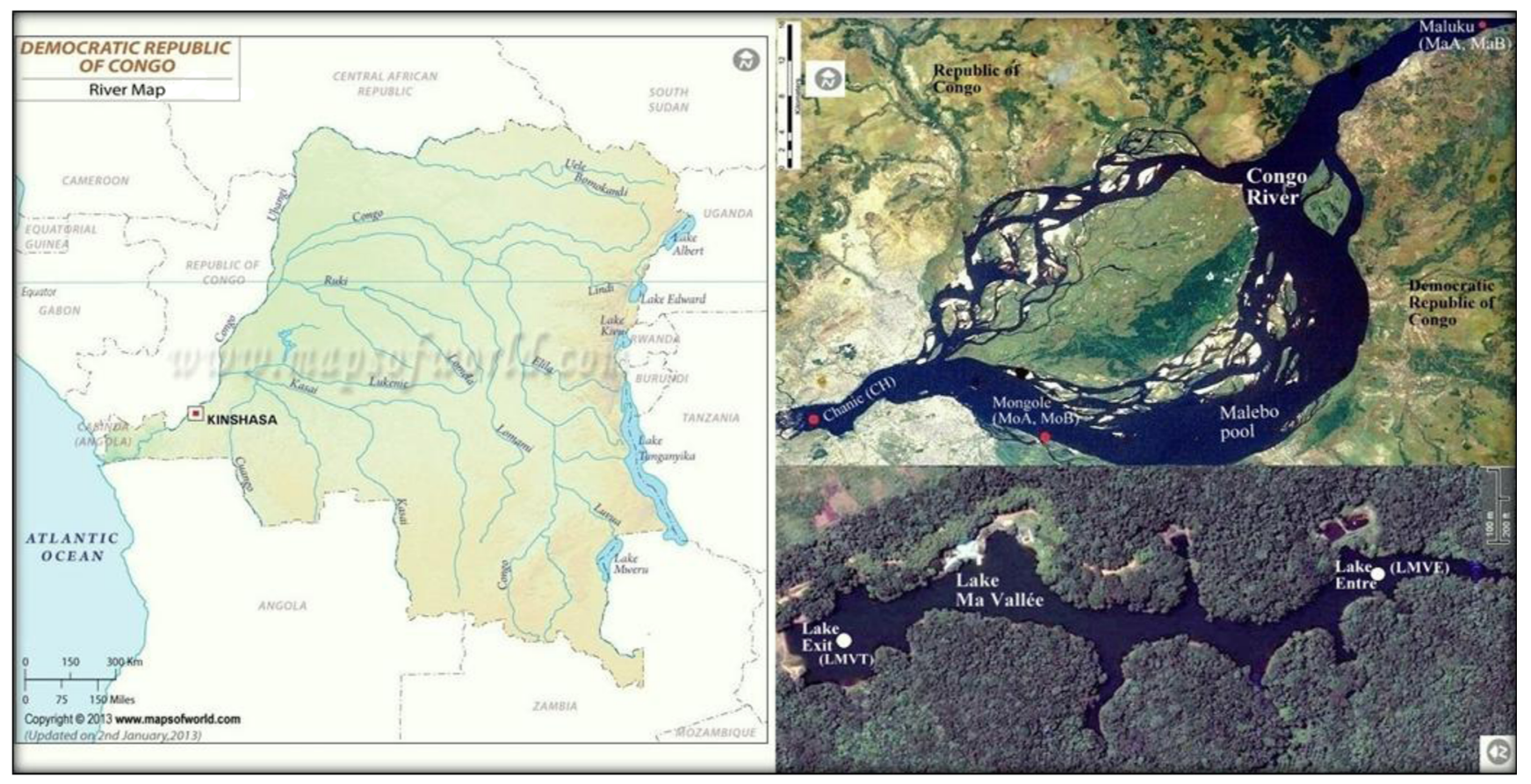

Fig. 1 Location map of study area, sampling sites, Congo River Basin and Lake Ma Vallée 
USA) at $850 \mathrm{~nm}$. Fifty milligrams of dry sediments was diluted in $5 \mathrm{~mL} \mathrm{HCl} 1 \mathrm{~N}$ and introduced in centrifuge tubes. The mixture was ultrasonicated at ambient temperature for $16 \mathrm{~h}$ and centrifuged $(4,000 \mathrm{rpm})$ for $20 \mathrm{~min}$. The supernatants were mineralised for $45 \mathrm{~min}$ at $130{ }^{\circ} \mathrm{C}$ after addition of $\mathrm{K}_{2} \mathrm{~S}_{2} \mathrm{O}_{8}$ solution (5\%). TP concentration was performed by measuring the absorbance of the blue complex obtained after reduction of molybdophosphoric acid according to the method described by Poté et al. (2008)
Heavy metal analysis by inductive coupled plasma-mass spectroscopy

The sediment samples were prepared as described by Thevenon et al. $(2012,2013)$ with minor modifications. Around $100 \mathrm{mg}$ of sediment powder was completely digested by pure acids in Teflon bombs heated by a glass ceramic hotplate. The procedure involves three heating steps followed by evaporation with (1) $1 \mathrm{ml} \mathrm{HNO}_{3}$ (suprapur, $65 \%$ ), (2) a mixture of $0.5 \mathrm{ml}$ of $\mathrm{HClO}_{4}$ (suprapur, $70 \%$ ) with $0.5 \mathrm{ml} \mathrm{HF}$ (suprapur, $40 \%$ ) and (3) one additional

Table 1 Sampling sites (GPS location) and sediment physicochemical characteristics

\begin{tabular}{|c|c|c|c|c|c|c|c|c|c|c|}
\hline Site & Latitude longitude & Sample no. & $\mathrm{H}_{2} \mathrm{O}(\%)$ & OM (\%) & $\mathrm{CaCO}_{3}(\%)$ & Grain size $(\mu \mathrm{m})$ & Silt (\%) & Clay $(\%)$ & Sand $(\%)$ & $\mathrm{TP}(\mathrm{ppm})$ \\
\hline \multirow{5}{*}{$\begin{array}{l}\text { Chanic } \\
\mathrm{CH}\end{array}$} & & $\mathrm{CH} 1$ & 30.95 & 7.62 & 1.81 & 110.20 & 0.19 & 31.70 & 68.11 & 378.58 \\
\hline & $4,331^{\circ}$ & $\mathrm{CH} 2$ & 29.91 & 6.37 & 1.77 & 108.20 & 0.21 & 31.70 & 68.09 & $\mathrm{n} / \mathrm{a}$ \\
\hline & $15,233^{\circ}$ & $\mathrm{CH} 3$ & 35.64 & 9.75 & 2.10 & 117.30 & 0.19 & 30.01 & 69.80 & 59.24 \\
\hline & & $\mathrm{CH} 4$ & 34.58 & 8.95 & 2.19 & 93.36 & 0.31 & 39.90 & 59.80 & 94.21 \\
\hline & & $\mathrm{CH} 5$ & 27.70 & 6.95 & 1.99 & 113.10 & 0.35 & 35.03 & 64.62 & 85.45 \\
\hline \multirow{5}{*}{$\begin{array}{l}\text { MONGOLE } \\
\text { MoA }\end{array}$} & & Mo1A & 45.50 & 12.02 & 3.31 & 46.22 & 0.43 & 58.89 & 40.69 & 597.27 \\
\hline & $4,323^{\circ}$ & $\mathrm{Mo} 2 \mathrm{~A}$ & 50.21 & 15.67 & 4.16 & 24.66 & 0.54 & 70.20 & 29.26 & 734.43 \\
\hline & $15,375^{\circ}$ & Mo3A & 54.34 & 17.45 & 4.76 & 19.34 & 0.55 & 74.18 & 25.28 & 793.86 \\
\hline & & $\mathrm{Mo} 4 \mathrm{~A}$ & 42.79 & 12.12 & 4.01 & 36.85 & 0.50 & 60.81 & 38.69 & 653.37 \\
\hline & & Mo5A & 21.98 & 12.95 & 1.35 & 75.69 & 0.21 & 40.56 & 59.23 & 115.36 \\
\hline \multirow{5}{*}{$\begin{array}{l}\text { MONGOLE } \\
\text { MoB }\end{array}$} & & Mo1B & 47.55 & 15.99 & 5.47 & 15.67 & 1.28 & 79.58 & 19.14 & 777.23 \\
\hline & $4,323^{\circ}$ & $\mathrm{Mo} 2 \mathrm{~B}$ & 47.83 & 15.89 & 5.31 & 16.88 & 0.90 & 75.98 & 23.12 & 758.42 \\
\hline & $15,375^{\circ}$ & Mo3B & 48.77 & 15.11 & 5.33 & 22.95 & 0.52 & 72.61 & 26.87 & 750.27 \\
\hline & & Mo4B & 44.83 & 13.02 & 4.76 & 20.36 & 0.76 & 76.56 & 22.68 & 575.55 \\
\hline & & Mo5B & 43.32 & 12.81 & 4.17 & 25.75 & 0.78 & 70.50 & 28.72 & 352.40 \\
\hline \multirow{5}{*}{$\begin{array}{l}\text { MALUKU } \\
\text { MaA }\end{array}$} & & Ma1A & 43.84 & 11.29 & 2.94 & 47.08 & 0.50 & 59.18 & 40.32 & 74.81 \\
\hline & $4,027^{\circ}$ & $\mathrm{Ma} 2 \mathrm{~A}$ & 35.60 & 7.38 & 2.03 & 62.16 & 0.27 & 50.28 & 49.45 & 125.58 \\
\hline & $15,609^{\circ}$ & Ma3A & 29.08 & 5.15 & 1.73 & 77.23 & 0.29 & 39.10 & 60.62 & 989.00 \\
\hline & & Ma4A & 32.38 & 6.94 & 2.28 & 69.51 & 0.28 & 45.75 & 53.97 & $7,821.21$ \\
\hline & & Ma5A & 40.08 & 9.06 & 2.36 & 78.80 & 0.16 & 41.65 & 58.19 & 160.84 \\
\hline \multirow{5}{*}{$\begin{array}{l}\text { MALUKU } \\
\text { MaB }\end{array}$} & & Ma1B & 30.00 & 5.17 & 1.76 & 85.19 & 0.34 & 31.96 & 67.70 & 89.16 \\
\hline & $4,027^{\circ}$ & $\mathrm{Ma} 2 \mathrm{~B}$ & 27.61 & 3.70 & 1.23 & 87.46 & 0.31 & 32.81 & 66.88 & 91.23 \\
\hline & $15,609^{\circ}$ & Ma3B & 20.75 & 2.00 & 0.72 & 101.00 & 0.05 & 15.94 & 84.01 & 787.35 \\
\hline & & Ma4B & 19.58 & 0.97 & 0.49 & 105.00 & 0.03 & 12.68 & 87.29 & 68.69 \\
\hline & & Ma5B & 19.95 & 1.59 & 0.67 & 103.60 & 0.02 & 16.04 & 83.94 & 96.07 \\
\hline \multirow{5}{*}{$\begin{array}{l}\text { Mavalee } \\
\text { entree }\end{array}$} & & Va1E & 15.87 & 1.95 & 1.02 & 214.80 & 1.09 & 15.11 & 83.80 & 90.07 \\
\hline & $4,498^{\circ}$ & Va2E & 17.25 & 1.80 & 1.17 & 208.10 & 1.23 & 16.68 & 82.09 & 301.13 \\
\hline & $15,281^{\circ}$ & Va3E & 17.13 & 1.94 & 1.35 & 217.60 & 1.08 & 14.38 & 84.54 & $1,616.60$ \\
\hline & & Va4E & 18.07 & 1.94 & 1.36 & 197.80 & 1.64 & 20.43 & 77.93 & $\mathrm{n} / \mathrm{a}$ \\
\hline & & Va5E & N/A & N/A & N/A & 171.30 & 2.26 & 26.90 & 70.84 & 753.15 \\
\hline \multirow{5}{*}{$\begin{array}{l}\text { Mavalee } \\
\text { exit }\end{array}$} & & Va1s & 18.87 & 2.35 & 1.50 & 275.10 & 0.99 & 12.94 & 86.07 & 777.50 \\
\hline & $4,492^{\circ}$ & Va2s & 21.71 & 3.07 & 1.74 & 243.80 & 1.08 & 15.71 & 83.21 & 339.66 \\
\hline & $15,281^{\circ}$ & Va3s & 19.16 & 3.21 & 1.78 & 228.60 & 1.86 & 19.34 & 78.80 & $2,122.96$ \\
\hline & & $\mathrm{Va} 4 \mathrm{~s}$ & 20.82 & 3.36 & 2.13 & 225.60 & 1.80 & 21.70 & 76.50 & $2,003.97$ \\
\hline & & Va5s & 20.00 & 3.44 & 2.23 & 198.20 & 2.12 & 23.83 & 74.05 & 715.61 \\
\hline
\end{tabular}


treatment with $0.5 \mathrm{ml}$ of $\mathrm{HNO}_{3}$ (suprapur, $65 \%$ ). The samples were evaporated between each step and finally diluted to $10 \mathrm{ml}$ with $1 \% \mathrm{HNO}_{3}$ solution for the measurement. The digested samples were analysed by inductive coupled plasma-mass spectroscopy (Agilent $7700 \times$ series ICP-MS developed for complex matrix analysis). A collision/reaction cell (helium mode) and interference equations are applied to remove spectral interferences that might otherwise bias results. Multielement standard solutions at different concentrations $\left(0,0.02,1,5,20,100\right.$ and $\left.200 \mu \mathrm{g} \mathrm{L}^{-1}\right)$ were used for calibration (Poté et al. 2008; Thevenon et al. 2013). Certified reference materials TMDA-70 and LKSD-2 and 4 were used for the sediment analysis, respectively, in order to verify the sensibility of the device and the reliability of the results. The results are expressed in $\mathrm{mg}$ $\mathrm{kg}^{-1}$ dry weight (ppm). The standard deviations of three replicate measurements were below $2.5 \%$, and chemical blanks for the procedure were less than $1 \%$ of the sample signal.

\section{Mercury analysis by AMA}

$\mathrm{Hg}$ analysis in sediment samples was carried out using atomic absorption spectrophotometry for mercury determination (Advanced Mercury Analyzer; AMA 254, Altec s.r.l., Czech Rep.) following the procedure described by Garcia Bravo et al. (2011). This method is based on sample combustion, gold amalgamation and atomic absorption spectrometry.

\section{Geoaccumulation index and enrichment factor}

The enrichment factor (EF) and geoaccumulation index $\left(I_{\text {geo }}\right)$ in sediment samples were calculated as described by Maanan et al. (2004), Varol (2011) and Thevenon et al. (2012, 2013). The geoaccumulation index is defined by the following equation:

$I_{\text {geo }}=\log _{2}\left(C_{\mathrm{n}}\right) / 1.5\left(B_{\mathrm{n}}\right)$
$C_{\mathrm{n}} \quad$ concentration of metals (n) examined in the sediment samples

$B_{\mathrm{n}} \quad$ concentration of the metal (n) geochemical background

1.5 lithospheric effect background correlation matrix factor

Enrichment factor is a useful tool to determine the degree of anthropogenic heavy metal pollution. EF is calculated using the following equation, and Sc was used for the geochemical normalization.

$\mathrm{EF}=($ metal $/ \mathrm{Sc})$ sample $/($ metal $/ \mathrm{Sc})$ background

Statistical analysis

Triplicate measurements have been performed on selected sediment samples. Statistical treatment of data (Pearson product moment correlation) has been realized using SigmaStat 11.0 (Systat Software, Inc., USA).

\section{Results}

\section{Sediment physicochemical characterization}

The physicochemical characteristics of the sediments, including particle size, organic matter (OM) and TP content of the sediment cores from sites CRB and LMV are reported in Table 1.

In $\mathrm{CRB}$, the percentage of clay and sand vary sensibly depending on the sampling sites and sediment depth, but the percentage of silts remains very low with values below $2 \%$. The sediments from the sites of Chanic $(\mathrm{CH})$ and Maluku (Ma) represent loamy sand sediments. The coarser sediments are found in these sites with the median values of 110 and $104 \mu \mathrm{m}$ for the sites $\mathrm{CH}$ and $\mathrm{Ma}$, respectively. The highest sand content is found in the sediments from $\mathrm{CH}$, ranging between 60 and $70 \%$. The total OM content of the sediments does not show considerable variation with sediment core depth; values range from 7 to 10,12 to 17,13 to 16,5 to 11 and 1 to $5 \%$ for the sites $\mathrm{CH}$,
Fig. 2 Photos of collection core samples from river Congo and Lake Ma Vallee using indigenous canoes

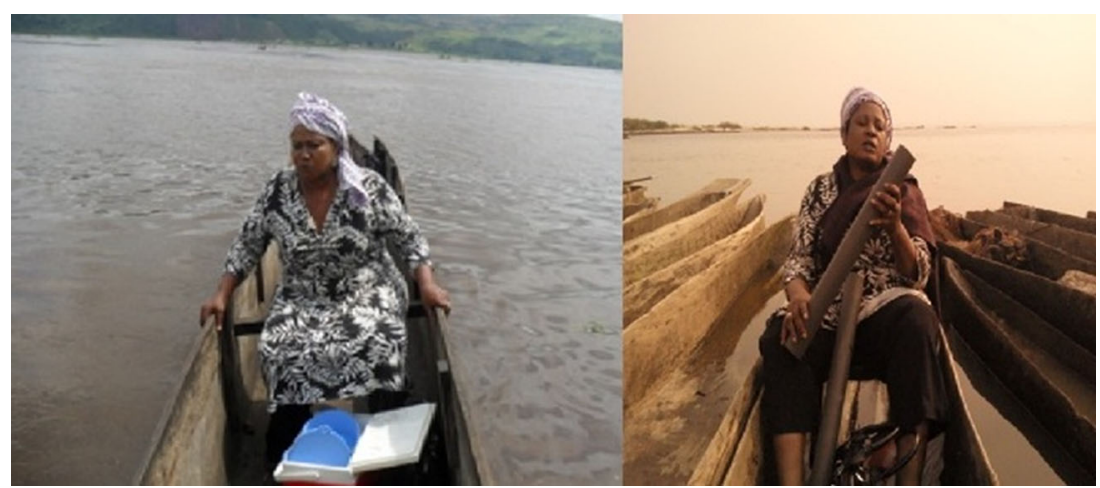




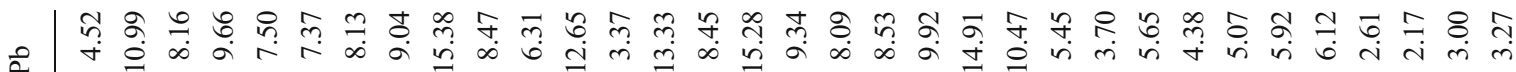
구

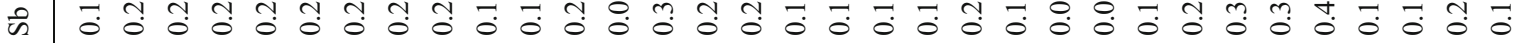

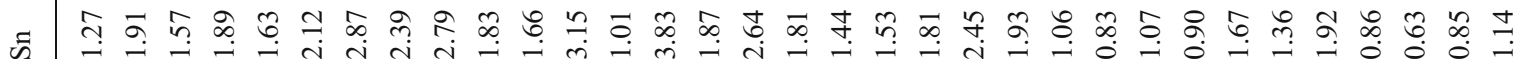

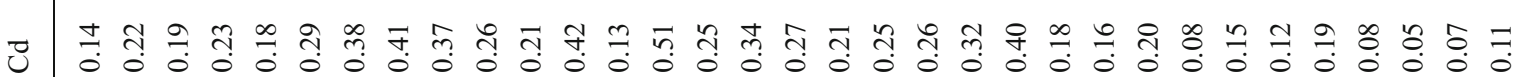

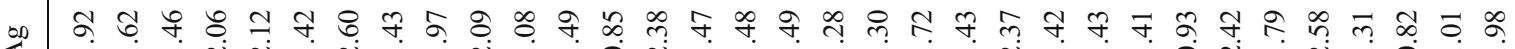
य

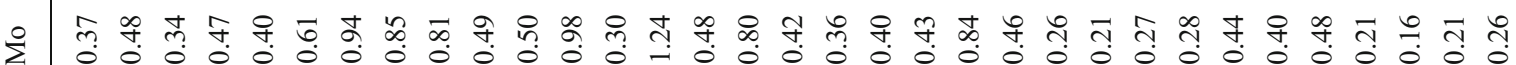

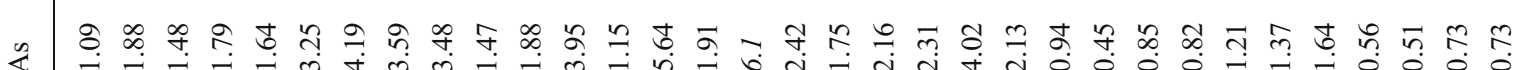

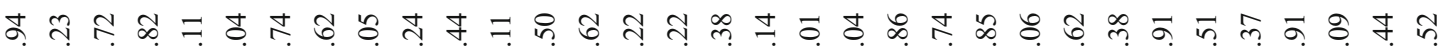

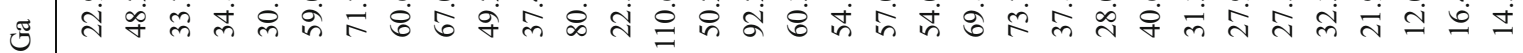

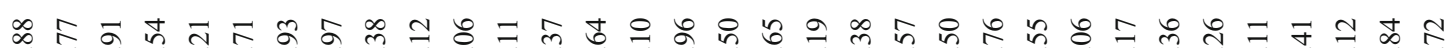

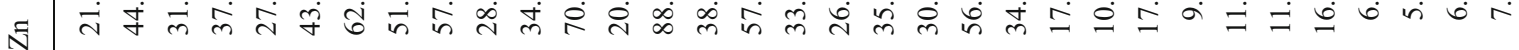

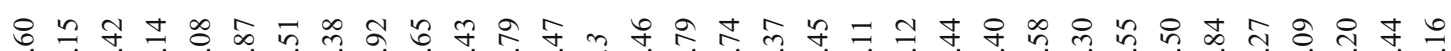

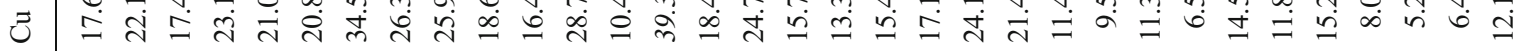
7 $\infty$ o z $\vec{f}$ त तु

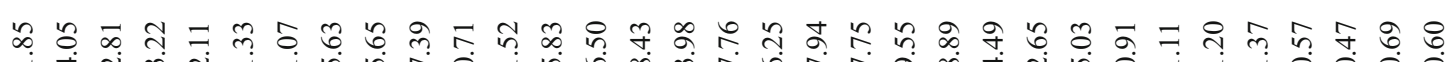
ठ $\rightarrow$ त

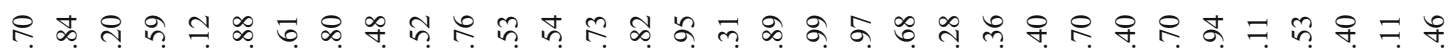
শై

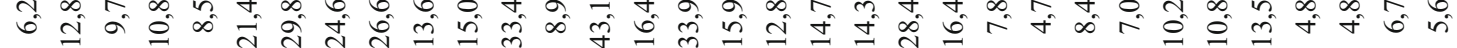

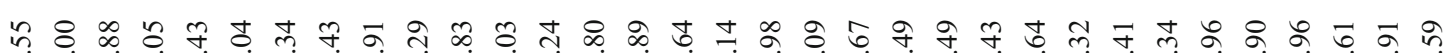

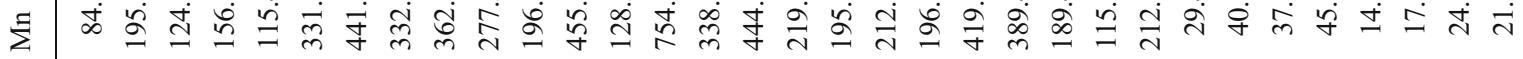

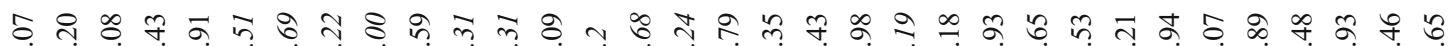

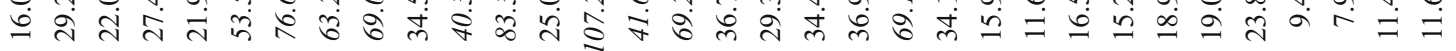

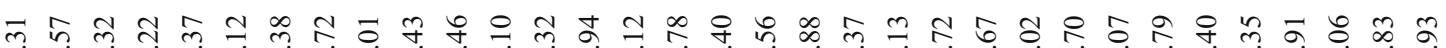
तี $\exists \infty$ 药

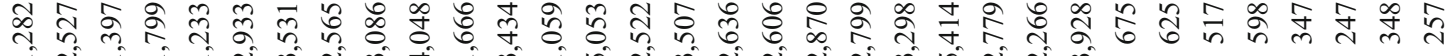

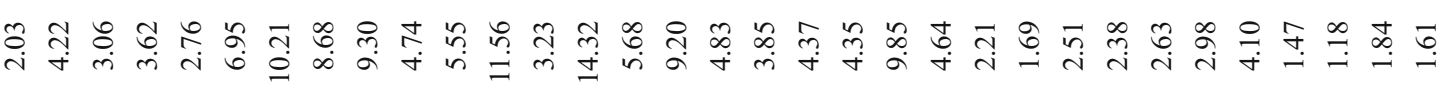
œ

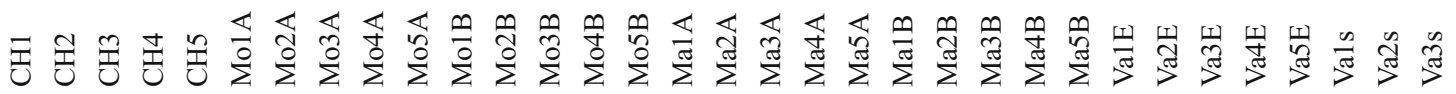

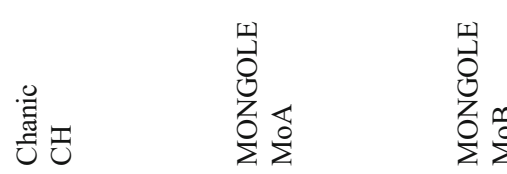
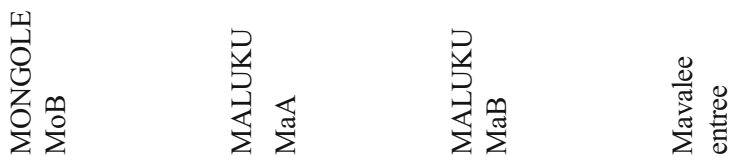

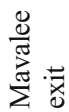


MoA, MoB, MaA and MaB, respectively. The lowest values for $\mathrm{TP}$ were observed in the sediment profile from the site of $\mathrm{CH}$, varying from 59 to $379 \mathrm{mg} \mathrm{kg}^{-1}$.

The coarsest sediments are observed in the sediment profiles from LVM with median grain size values ranging from 171 to 217 and 198 to $275 \mu \mathrm{m}$ for the sites LMVaE and LMVaS, respectively. The sediments from these sites are sandy sediments with values of 71 to $84 \mu \mathrm{m}$ and 74 to $86 \mu \mathrm{m}$ for the sites LMVaE and LMVaS, respectively. These sediments present the lowest values of OM, with maximum values of 2.0 and $3.4 \%$ for LMVE and LMVT, respectively. The total phosphorus contents vary considerably with sediment core depths. In both sites, the maximum values of TP are found in the deepest sediments, 1,617 and $2,123 \mathrm{mg} \mathrm{kg}^{-1}$ for the sites LMVaE and LMVaS, respectively.

Sediment metal content and distribution

The concentration of trace elements ( $\mathrm{Sc}, \mathrm{Ti}, \mathrm{V}, \mathrm{Cr}, \mathrm{Mn}, \mathrm{Fe}, \mathrm{Co}$, $\mathrm{Ni}, \mathrm{Cu}, \mathrm{Zn}, \mathrm{Ga}, \mathrm{As}, \mathrm{Mo}, \mathrm{Ag} \mathrm{Cd}, \mathrm{Sn}, \mathrm{Sb}$ and $\mathrm{Pb}$ ) in the sediment profiles from CRB and LMV are shown in Table 2. Concentrations of metals within distinct sediment profiles vary moderately. For example, in the sediment core from the site $\mathrm{CH}$, the range of concentrations are 17.42-23.14, 1.85$4.05,23.09-47.41,16.07-29.20$ and $4.52-10.99 \mathrm{mg} \mathrm{kg}^{-1}$ for $\mathrm{Cu}, \mathrm{Co}, \mathrm{Ni}, \mathrm{Cr}$, and $\mathrm{Pb}$, respectively. For the sediment core from pool Malebo (MoA), the range of concentrations are 18.65-34.51, 7.39-21.07, 28.19-111.69, 34.59-76.69 and $7.37-15.38 \mathrm{mg} \mathrm{kg}^{-1}$ for $\mathrm{Cu}, \mathrm{Co}, \mathrm{Ni}, \mathrm{Cr}$ and $\mathrm{Pb}$ respectively. For the area of Maluku (MaA) the range of concentrations are 13.37-24.79, 6.25-13.98, 24.97-38.55, 29.35-69.24 and 8.09-16.28 $\mathrm{mg} \mathrm{kg}^{-1}$ for $\mathrm{Cu}, \mathrm{Co}, \mathrm{Ni}, \mathrm{Cr}$ and $\mathrm{Pb}$, respectively. In general, the upper sediment samples $(0-3 \mathrm{~cm})$ present the lowest metal concentration, whereas the higher metal values are observed in the sediment samples from $4-$ to $6-\mathrm{cm}$ core depth. The maximum concentration for all analysed metals is found in the area of pool Malebo, sites MoA and MoB. In this area, the major trace elements, as well as $\mathrm{Ti}, \mathrm{Fe}$ and $\mathrm{Mn}$ present the highest concentrations. The mercury $(\mathrm{Hg})$ analysis was performed only in the sediments sampled from the site MoA. The range of concentration is 0.04 $4.7 \mathrm{mg} \mathrm{kg}$. Similarly to other metals, the maximum value of $4.7 \mathrm{mg} \mathrm{kg}^{-1}$ for $\mathrm{Hg}$ is observed in the sample taken at $4-6 \mathrm{~cm}$ in the sediment core MoA.

For LMV sediment cores, in general, all the metals present a relatively similar evolution pattern throughout the sediment profiles. In contrast to the metal concentration values in the sediments of core $\mathrm{CRB}$, the maximum metal concentrations in LMV sediments are observed in the uppermost part of the core (0-3-cm layer). The maximum values of 15.27 , $1.53,53.63,23.89$ and $6.51 \mathrm{mg} \mathrm{kg}^{-1}$ for $\mathrm{Cu}, \mathrm{Co}, \mathrm{Ni}$, $\mathrm{Cr}$ and $\mathrm{Pb}$ were observed, respectively. 
Table $3 \mathrm{EF}$ and $I_{\text {geo }}$ values for $\mathrm{Co}, \mathrm{Ni}$ and $\mathrm{Cu}$ in the sediment core profiles

\begin{tabular}{|c|c|c|c|c|c|c|c|}
\hline & & & Igeo & & & $\mathrm{EF}$ & \\
\hline $\begin{array}{c}\text { Sample } \\
\text { area }\end{array}$ & $\begin{array}{l}\text { Sample } \\
\text { number }\end{array}$ & Co & $\mathrm{Ni}$ & $\mathrm{Cu}$ & $\mathrm{Co}$ & $\mathrm{Ni}$ & $\mathrm{Cu}$ \\
\hline \multirow{5}{*}{ 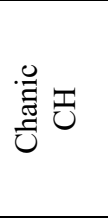 } & CH1 & 2.04 & 3.98 & 5.29 & 3.04 & 11.66 & 4.33 \\
\hline & $\mathrm{CH} 2$ & 3.17 & 3.21 & 5.62 & 3.20 & 3.28 & 2.63 \\
\hline & $\mathrm{CH} 3$ & 2.64 & 2.94 & 5.27 & 3.07 & 3.78 & 2.85 \\
\hline & $\mathrm{CH} 4$ & 2.84 & 3.83 & 5.68 & 2.96 & 5.89 & 3.19 \\
\hline & $\mathrm{CH} 5$ & 2.23 & 3.65 & 5.55 & 2.55 & 6.84 & 3.83 \\
\hline \multirow{5}{*}{ 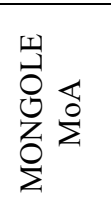 } & Mo1A & 4.65 & 3.97 & 5.54 & 5.43 & 3.39 & 1.48 \\
\hline & Mo2A & 5.55 & 5.22 & 6.26 & 6.88 & 5.47 & 1.25 \\
\hline & Mo3A & 5.12 & 4.85 & 5.87 & 6.00 & 5.00 & 1.62 \\
\hline & Mo4A & 5.12 & 3.95 & 5.85 & 5.61 & 2.49 & 1.37 \\
\hline & Mo5A & 4.04 & 3.23 & 5.37 & 5.20 & 2.97 & 1.63 \\
\hline \multirow{5}{*}{ 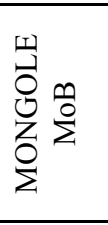 } & Mo1B & 4.57 & 3.43 & 5.19 & 6.43 & 2.92 & 1.50 \\
\hline & Mo2B & 5.58 & 4.76 & 6.00 & 6.20 & 3.53 & 1.69 \\
\hline & Mo3B & 3.69 & 3.02 & 4.54 & 6.01 & 3.76 & 1.52 \\
\hline & Mo4B & 5.88 & 4.84 & 6.45 & 6.17 & 2.99 & 1.39 \\
\hline & Mo5B & 4.23 & 3.75 & 5.36 & 4.95 & 3.57 & 1.97 \\
\hline \multirow{5}{*}{ 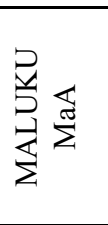 } & Ma1A & 4.96 & 3.68 & 5.78 & 5.07 & 2.10 & 1.35 \\
\hline & $\mathrm{Ma} 2 \mathrm{~A}$ & 4.11 & 3.06 & 5.13 & 5.36 & 2.59 & 1.63 \\
\hline & Ma3A & 3.8 & 3.17 & 4.89 & 5.42 & 3.51 & 1.74 \\
\hline & $\mathrm{Ma} 4 \mathrm{~A}$ & 4.14 & 3.13 & 5.10 & 6.06 & 3.01 & 1.77 \\
\hline & Ma5A & 4.11 & 3.28 & 5.25 & 5.93 & 3.34 & 1.96 \\
\hline \multirow{5}{*}{ 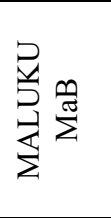 } & Ma1B & 5.44 & 3.72 & 5.74 & 6.61 & 2.00 & 1.22 \\
\hline & Ma2B & 4.3 & 3.61 & 5.57 & 6.39 & 3.96 & 2.31 \\
\hline & Ma3B & 3.32 & 2.88 & 4.66 & 6.77 & 4.99 & 2.58 \\
\hline & Ma4B & 2.56 & 2.64 & 4.41 & 5.21 & 5.51 & 2.83 \\
\hline & Ma5B & 3.48 & 2.79 & 4.65 & 6.69 & 4.14 & 2.25 \\
\hline \multirow{5}{*}{ 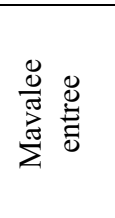 } & LMVa1E & 1.02 & 1.56 & 1.13 & 1.28 & 1.86 & 1.38 \\
\hline & LMVa2E & 1.3 & 2.56 & 2.27 & 1.41 & 3.38 & 2.76 \\
\hline & LMVa3E & 1.41 & 2.42 & 1.98 & 1.34 & 2.70 & 1.99 \\
\hline & LMVa4E & 1.6 & 2.79 & 2.36 & 1.11 & 2.53 & 1.87 \\
\hline & LMVa5E & 0.33 & 3.04 & 1.43 & 1.28 & 8.38 & 2.75 \\
\hline \multirow{5}{*}{ 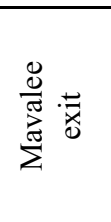 } & LMVa1S & 0.05 & 1.18 & 0.79 & 1.32 & 2.89 & 2.21 \\
\hline & LMVa2S & 0.61 & 2.42 & 1.10 & 1.24 & 4.37 & 1.75 \\
\hline & LMVa3S & 0.43 & 3.49 & 2.02 & 1.25 & 10.46 & 3.77 \\
\hline & LMVa4S & 0 & 6.4 & 2.12 & 1.58 & 133.30 & 6.87 \\
\hline & LMVa5S & 1.76 & 3.73 & 2.26 & 1.26 & 4.92 & 1.77 \\
\hline
\end{tabular}

Igeo classification (Varol et al 2011)

$\begin{array}{ll}\text { Igeo } \leq 0 & \text { Class } 0 \text { - practically unpolluted } \\ 0<\text { Igeo }<1 & \text { Class } 1-\text { unpolluted to moderately polluted } \\ 1<\text { Igeo }<2 & \text { Class } 2 \text { - moderately polluted } \\ 2<\text { Igeo }<3 & \text { Class } 3 \text { - moderately to heavily polluted } \\ 3<\text { Igeo }<4 & \text { Class } 4 \text { - heavily polluted } \\ 4<\text { Igeo }<5 & \text { Class } 5 \text { - heavily to extremely polluted } \\ 5>\text { Igeo } & \text { Class } 6 \text { - extremely polluted }\end{array}$

EF values interpretation (Sakan et al 2009)

$\begin{array}{ll}\mathrm{EF}<1 & \begin{array}{l}\text { indicates no enrichment } \\ \text { minor enrichment }\end{array} \\ \mathrm{EF}<3 & \text { moderate enrichment } \\ \text { EF } 3-5 & \text { moderately severe enrichment } \\ \text { EF } 5-10 & \text { severe enrichment } \\ \text { EF } 10-25 & \text { very severe enrichment } \\ \text { EF } 25-50 & \text { extremely severe enrichment }\end{array}$




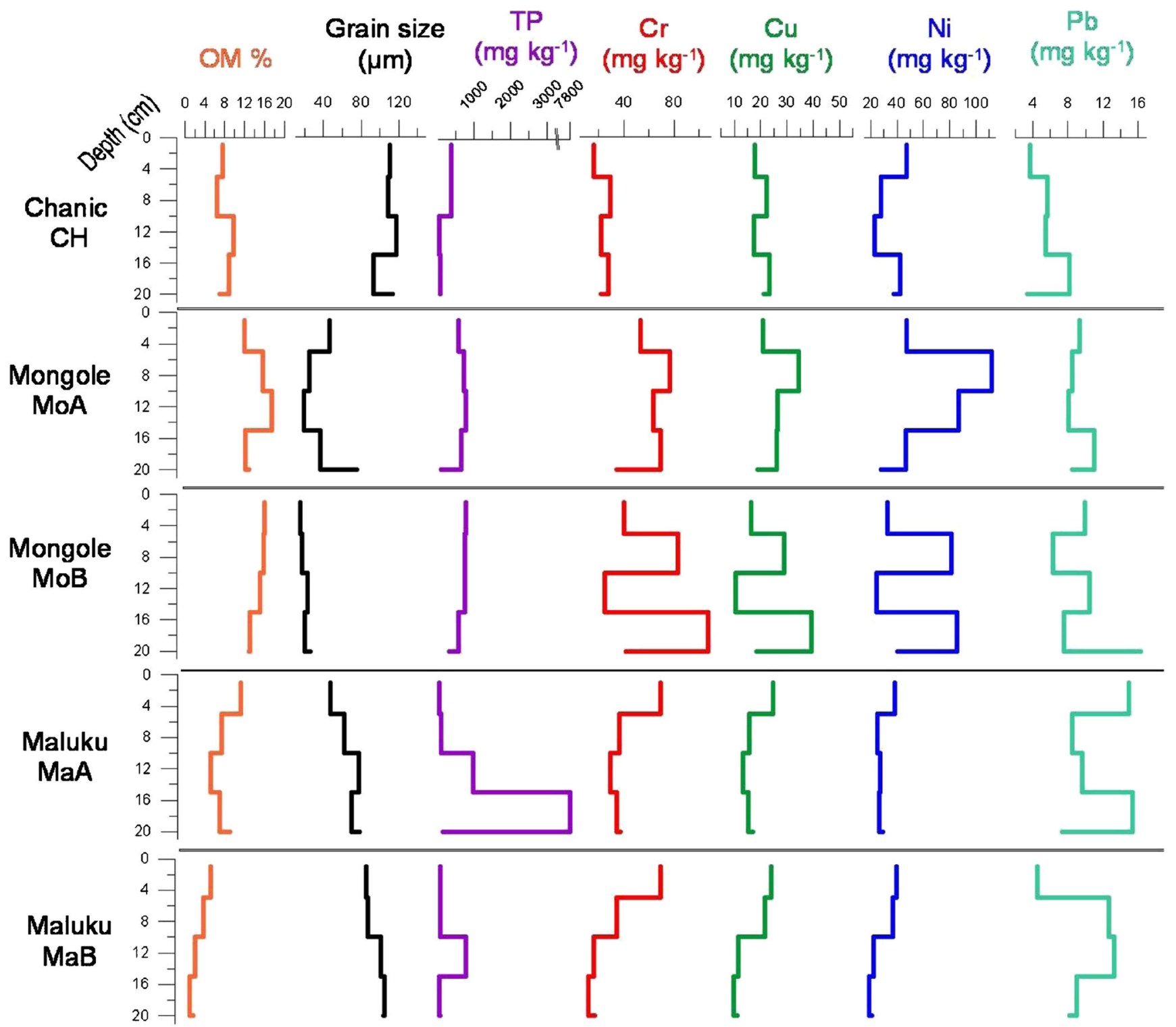

Fig. 3 Depth pattern distribution of organic matter and some metals in sediment profiles from Congo River Basin

Enrichment assessment

The results of the calculation of the enrichment factors (EF) and $I_{\text {geo }}$ are presented in Table 3. The highest values of EF and $I_{\text {geo }}$ for all selected metals are found in the area of pool Malebo, while non-negligible values are found in the other areas of CRB. EF and $I_{\text {geo }}$ values from LMV are very low except for Va4S which corresponds to $6.4 I_{\text {geo }}$ and $133.3 \mathrm{EF}$ values. The pollution index $\left(I_{\text {geo }}\right)$ ranges from 2.04 to 6.26 in $\mathrm{CRB}$ and 0 to 6.4 in LMV. The contamination levels of the metals range from 1.22 to 11.66 in $\mathrm{CRB}$.

\section{Discussion}

Metal distribution in the sediments

The depth distribution patterns for OM, grain size, TP and trace elements $(\mathrm{Cr}, \mathrm{Cu}, \mathrm{Ni}$ and $\mathrm{Pb})$ in sediment cores are shown in Figs. 3 and 4 for sediment samples from CRB and LMV, respectively. In CRB, except for the upper sediments which show lower values of metals, all the analysed metals seem to be uniformly distributed with sediment core depth. The pollution level in the surface sediments $(0-3 \mathrm{~cm})$ in the sampling areas of CRB may be possibly explained by the 


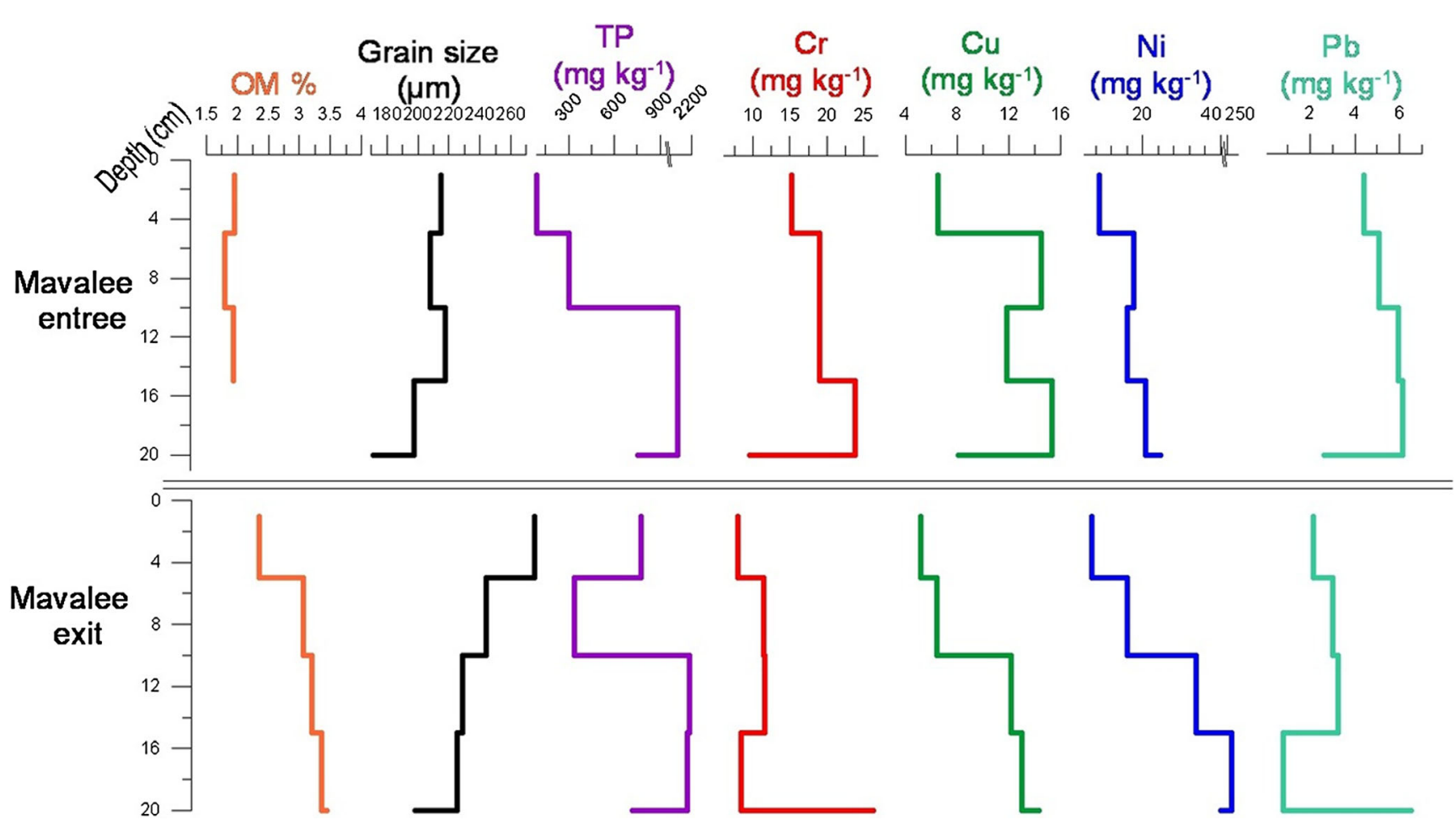

Fig. 4 Depth pattern distribution of organic matter and some metals in sediment profiles from Lake Ma Vallée

slowdown of the regional economic activities during the last decades. Conversely, the levels of metals are relatively high in the area of pool Malebo, indicating a probable local source of contamination. This site is characterized by intense human activities involving commerce and industries for the construction of boats used for the regular navigation along the river. The border of the Congo River in this area is also used as a landfill for solid wastes by the local population. Additionally, the input of Ngwele River (named Ndjili which collects the majority of drained urban water of the city of Kinshasa, as well as industrial untreated effluent waters) into Congo River is located in the vicinity of this site. For LMV, in general, the metal

Table 4 Pearson product moment correlation matrix of selected parameters analysed in the studied samples for $\mathrm{Cr}, \mathrm{Ni}, \mathrm{Cu}, \mathrm{Pb}$, organic matter, particle grain size and total phosphorus from the site of pool Malebo

\begin{tabular}{|c|c|c|c|c|c|c|}
\hline & $\mathrm{Ni}$ & $\mathrm{Cu}$ & $\mathrm{Pb}$ & $\mathrm{OM}$ & Grain size & TP \\
\hline $\mathrm{Cr}$ & 0.74 & 0.67 & 0.72 & 0.33 & -0.74 & -0.08 \\
\hline $\mathrm{Ni}$ & & 0.85 & 0.75 & 0.69 & -0.75 & -0.04 \\
\hline $\mathrm{Cu}$ & & & -0.03 & 0.26 & -0.09 & 0.12 \\
\hline $\mathrm{Pb}$ & & & & 0.66 & -0.67 & -0.10 \\
\hline $\mathrm{OM}$ & & & & & -0.64 & -0.11 \\
\hline Grain size & & & & & & -0.03 \\
\hline
\end{tabular}

Correlation coefficients have been calculated using the log value of the parameter contents to normalize their distribution. Statistically significant coefficients $(p<0.05)$ are in italics levels appear to be uniformly distributed with sediment depth, and the concentrations of all metals are generally low. For all depth, the maximum levels of some toxic metals were (in $\mathrm{mg} \mathrm{kg}^{-1}$ ) $6.12(\mathrm{~Pb}), 15.27(\mathrm{Cu}), 26.26$ $(\mathrm{Cr})$ and $14.83(\mathrm{Zn})$. According to the enrichment factor as will be described later, it seems that there are moderate anthropogenic inputs. The levels of trace metals in sediments of LMV can be explained in major part by input from lithological material in the region. The difference levels of the metals in sediment samples from the entrance and the exit of lake, as well as sediment depth, can be explained by the sediment physico-chemical characterization, mainly the particle grain size and organic matter content (Garcia Bravo et al. 2011; Poté et al. 2008; Salonen and Korkka-Niemi 2007).

In comparison to the other studies performed in the Katanga mining region of DRC (copper-cobalt belt) on the assessment of trace elements in water and sediments, the sediments from CRB present much lower values of toxic metals (Banza et al. 2009; Mees et al. 2013; Atibu et al. 2013). For example, in the surface sediments of Luilu River, the values of 47,468 and $13,199 \mathrm{mg} \mathrm{kg}^{-1}$ were observed for $\mathrm{Cu}$ and $\mathrm{Co}$, respectively, whereas for the sediment samples from Musonoie River, the values of 370.8 and $240.6 \mathrm{mg} \mathrm{kg}^{-1}$ are respectively observed for $\mathrm{Cu}$ and Co (Atibu et al. 2013). These results indicated that mining activities are a great source of metal pollution for the streams and rivers of the Katanga region with alarming metal levels in local water supplies. 
Indices of sediment contamination

The assessment of sediment profiles was performed using enrichment factor $(\mathrm{EF})$ and geoaccumulation index $\left(I_{\mathrm{geo}}\right)$. These indices are important to discriminate anthropogenic metals and give a quantitative criterion for characterizing the sediment according to the degree of metal pollution (Adamo et al. 2005). The $I_{\text {geo }}$ classification of extremely polluted sediments are more abundant among the samples from the CRB (Mongole) samples, and the classification of unpolluted to moderately polluted sediments are more frequent in the samples from LMV. Based on the values from $I_{\text {geo }}$ and EF calculations, the level of metal contamination follows the order of these sampling sites: Mongole $>$ Maluku $>$ Chanic $>$ Mavalee. According to Zhang and Liu (2000), EF values ranging between 0.05 and 1.5 indicate that the metal is entirely from crustal origin and deposited due to natural processes (runoff and erosion), while the EF values above 1.5 suggest that the sources are likely to be anthropogenic. According to this classification and to the EF values of the studied samples (Table 3), our results suggest that the metals from the LMV are mostly from natural source, while the anthropogenic degree of pollution is relatively low for most of the studied samples. Conversely, the values of CRB represent a strong anthropogenic pollution rather than natural deposition of trace metals.

\section{Correlation between sediment characteristics}

and concentration of toxic metals

All the analysed metals show positive correlation between different samples. Table 4 shows that the trace elements $\mathrm{Cr}$, $\mathrm{Ni}, \mathrm{Cu}, \mathrm{Pb}$ and organic matter content are positively correlated with a significant value $(P<0.05)$. This correlation matrix provides further evidence that all the trace elements could have originated from the same type of source with a similar transport pathway (runoff and streams) (Poté et al. 2008; Haller et al. 2009). The behaviour of total phosphorus is an exception to the above observation as there is no significant correlation between the organic matter, particle grain size and metals when compared with total phosphorus. On the other hand, the correlation matrix with the particle grain size indicates a negative correlation for the all the studied samples with correlation matrix values between -0.64 to -0.78 , suggesting that organic (OM and phosphorus) and inorganic (natural trace elements) input is controlled by the fraction of the fine sediment (clay).

\section{Conclusion}

This is one of the first geochemical analyses of sediment from the Congo River Basin and Lake Ma Vallée (Mwanamoki et al. 2014a, b), located in the vicinity of the city of Kinshasa.
As far as we know, the average geochemical composition of the upper continental earth crust of the Congo Basin has not been investigated systematically up to now. Therefore, the geochemical background values for our investigation remain unknown. When compared to the global average composition of the upper continental earth crust (Rudnick and Gao 2003), the content of measured metals, such us $\mathrm{V}, \mathrm{Cr}, \mathrm{Co}, \mathrm{Ni}, \mathrm{Cu}, \mathrm{As}$, $\mathrm{Mo}$ and $\mathrm{Sn}$ is lower in the sediments. Higher values have been measured for $\mathrm{Ag}, \mathrm{Cd}$ and $\mathrm{Hg}$, mainly in the site of pool Malebo. As a consequence, human impact on the metal concentrations in general cannot be deduced from the geochemical sediment composition. Also, when considering variations found in sediment cores (Figs. 3 and 4), such influences, mainly by human activities and the presence of uncontrolled landfills, cannot be excluded. Regarding toxic effects of metal concentration, the natural or man-made origin is not questioned. Thus, further studies with more sediment samples from the river are recommended to fully evaluate the other potential sources of contamination as well as the ecotoxicological effects.

Acknowledgments We are grateful to financial sources from the Swiss National Science Foundation (grant no. 31003A_150163/1) and Forel Institute, University of Geneva. This research presents the results of a tripartite collaboration between University of Geneva (Forel Institute), University of Kinshasa and Pedagogic National University of Congo (Democratic Republic of Congo) and Jamal Mohamed College (affiliated to Bharathidasan University) Tiruchirappalli, Tamil Nadu, India. Naresh Devarajan is a Ph.D. scholar supported by Swiss Government Scholarships for Foreign Scholars.

\section{References}

Adamo P, Arienzo M, Imperato M, Naimo D, Nardi G, Stanzione D (2005) Distribution and partition of heavy metals in surface and subsurface sediments of Naples city port. Chemosphere 61:800-809

Atibu EK, Devarajan N, Thevenon F, Mwanamoki PM et al (2013) Concentration of metals in surface water and sediment of Luilu and Musonoie Rivers, Kolwezi-Katanga, Democratic Republic of Congo. Appl Geochem 39:26-32

Banza CLN, Nawrot T, Haufroid V et al (2009) High human exposure to cobalt and other metals in Katanga. Environ Res 109:745-752

Brayner FMM, da Silva HKP, de Freitas Barbosa AM (2001) Speciation of heavy metals in estuarine sediments in the northeast of Brazil. Environ Sci Pollut Res 8:269-274

CCME EPC-98E (Conseil Canadien des Ministres de l'Environnement) (1999) Introduction, dans Recommandations canadiennes pour la qualité de l'environnement. Winnipeg, le Conseil

Davies CM, Long JAH, Donald M, Ashbolt N (1995) Survival of fecal microorganisms in marine and freshwater sediments. Appl Environ Microbiol 61:1888-1896

Dupré B, Gaillardet J, Rousseau D, Allègre CJ (1996) Major and trace elements of river-borne material: the Congo Basin. Geochim Cosmochim Acta 60:1301-1321

Förstner U, Wittmann GTW (1979) Metal pollution in the aquatic environment. Springer-Verlag, Berlin, $486 \mathrm{p}$ 
Garcia Bravo A, Bouchet S, Amouroux D, Poté J, Dominik J (2011) Distribution of mercury and organic matter in particlesize classes in sediments contaminated by a waste water treatment plant: Vidy Bay, Lake Geneva, Switzerland. J Environ Monit 13:974-982

Gnandi K, Han S, Rezaie-Boroon H, Porrachia M, Deheyn DD (2011) Increased bioavailability of mercury in the lagoons of Lome', Togo: the possible role of dredging. AMBIO 40:26-42

Haller L, Poté J, Loizeau J-L, Wildi W (2009) Distribution and survival of faecal indicator bacteria in the sediments of the Bay of Vidy, Lake Geneva, Switzerland. Ecol Indic 9:540-547

Haller L, Tonolla M, Zopfi J, Peduzzi R, Wildi W, Poté J (2011) Composition of bacterial and archaeal communities in freshwater sediments with different contamination levels. (Lake Geneva, Switzerland) Water Res 45:1213-1228

Hu B, Li G, Li J, Bi J, Zhao J, Bu R (2013) Spatial distribution and ecotoxicological risk assessment of heavy metals in surface sediments of the southern Bohai Bay, China. Environ Sci Pollut Res 20: $4099-4110$

Kambole MS (2003) Managing the water quality of the Kafue River. Phys Chem Earth 28:1105-1109

Kang JS, Kim DJ, Jang DD (2000) The modifying effect of indole-3carbinol (I3C) and its metabolites, phytochemicals from Cruciferae vegetables, in chemical carcinogenesis and cancer prevention. $\mathrm{J}$ Korean Assoc Cancer Prev 5:199-208

Key RM, De Waele B, Liyungu AK (2004) A multi-element baseline geochemical database from the western extension of the Central Africa: copperbelt in northwestern Zambia. Appl Earth Sci 113: 205-226

Loizeau J-L, Arbouillle D, Santiago S, Vernet J-P (1994) Evaluation of a wide range laser diffraction grain size analyser for use with sediments. Sedimentology 41:353-361

Maanan M, Zourarah B, Carruesco C, Aajjane A, Naud J (2004) The distribution of heavy metals in the Sidi Moussa lagoon sediments (Atlantic Moroccan Coast). J Afr Earth Sci 39:473-483

Mees F, Maselehdani MNN, De Putter T, D'Hollander C, Van Biezen E, Mujinya BB, Potdevin JL, Van Ranst E (2013) Concentration and forms of heavy metals around two ore processing sites in Katanga, Democratic Republic of Congo. J Afr Earth Sci 77:22-30

Mubedi JI, Devarajan N, Le Faucheur S, Kayembe MJ, Atibu EK, Sivalingam P, Prabakar P, Mpiana TP, Wildi W, Poté J (2013) Effects of untreated hospital effluents on the accumulation of toxic metals in sediments of receiving system under tropical conditions: case of South India and Democratic Republic of Congo. Chemosphere 93:1070-1076

Mwanamoki PM, Devarajan N, Thevenon F, Niane B, de Alencastro LF, Grandjean D, Mpiana PT, Prabakar K, Mubedi JI, Kabele CG, Wildi W, Poté J (2014a) Trace metals and persistent organic pollutants in sediments from river-reservoir systems in Democratic Republic of Congo (DRC): spatial distribution and potential ecotoxicological effects. Chemosphere 111:485-492

Mwanamoki PM, Devarajan N, Thevenon F, Atibu EK, Tshibanda JB, Ngelinkoto P, Mpiana PT, Prabakar K, Mubedi JI, Kabele CG, Wildi W, Poté J (2014b) Assessment of pathogenic bacteria in water and sediment from a water reservoir under tropical conditions (Lake Ma Vallée) Kinshasa Democratic Republic of Congo. Environ Monit Assess. doi:10.1007/s10661-014-3891-6
Ngelinkoto P, Thevenon F, Devarajan N, Birane N, Maliani J, Buluku A, Musibono D, Mubedia IJ, Poté J (2014) Trace metal pollution in aquatic sediments and some fish species from the Kwilu-Ngongo River, Democratic Republic of Congo (Bas-Congo). Toxicol Environ Chem. doi:10.1080/02772248.2014.910211

Poté J, Haller L, Loizeau J-L, Garcia Bravo A, Sastre V, Wildi W (2008) Effects of a sewage treatment plant outlet pipe extension on the distribution of contaminants in the sediments of the Bay of Vidy, Lake Geneva, Switzerland. Bioresour Technol 9:7122-7131

Redeker ES, Bervoets L, Blust R (2004) Dynamic model for the accumulation of cadmium and zinc from water and sediment by the aquatic oligochaete, Tubifex tubifex. Environ Sci Technol 38: 6193-6200

Rudnick RL, Gao S (2003) Composition of the continental crust. In: Heinrich D, Holland HD, Turekian KK (eds) Treatise on geochemistry. Elsevier, Oxford, p 65

Salonen VP, Korkka-Niemi K (2007) Influence of parent sediments on the concentration of heavy metals in urban and suburban soils in Turku, Finland. Appl Geochem 22:906-918

Schwarzenbach RP, Escher BI, Fenner K, Hofstetter TB, Johnson CA, von Gunten U, Wehrli B (2006) The challenge of micropollutants in aquatic systems. Science 313:1072-1077

Thevenon F, Poté J (2012) Water pollution history of Switzerland recorded by sediments of the large and deep perialpine lakes Lucerne and Geneva. Water Air Soil Pollut 223:6157-6169

Thevenon F, Graham ND, Chiaradia M, Arpagaus P, Wildi W, Poté J (2011a) Local to regional scale industrial heavy metal pollution recorded in sediments of large freshwater lakes in Central Europe (lakes Geneva and Lucerne) over the last centuries. Sci Total Environ 412-413:239-247

Thevenon F, Guédron S, Chiaradia M, Loizeau J-L, Pote J (2011b) (Pre-) historic changes in natural and anthropogenic heavy metals deposition inferred from two contrasting Swiss Alpine lakes. Quat Sci Rev 30:224-233

Thevenon F, Regier N, Benagli C, Tonolla M, Adatte T, Wildi W, Poté J (2012) Characterization of faecal indicator bacteria in sediments cores from the largest freshwater lake of Western Europe (Lake Geneva, Switzerland). Ecotox Environ Safety 78: 50-56.

Thevenon F, Adatte T, Wildi W, Poté J (2013) A high-resolution historical sediment record of nutrients, trace elements and organochlorines (DDT and PCB) deposition in a drinking water reservoir (Lake Brêt, Switzerland) points at local and regional pollutant sources. Chemosphere 90:2444-2452

Varol M (2011) Assessment of heavy metal contamination in sediments of the Tigris River (Turkey) using pollution indices and multivariate statistical techniques. J Hazard Mater 195:355-364

Verhaert V, Covaci A, Bouillon S, Abrantes K, Musibono D, Bervoets L, Verheyen E, Blust R (2013) Baseline levels and trophic transfer of persistent organic pollutants in sediments and biota from the Congo River Basin (DR Congo). Environ Int 59:290-302

Vörösmarty CJ, McIntyre PB, Gessner MO, Dudgeon D, Prusevich A, Green P, Glidden S, Bunn SE, Sullivan CA, Liermann CR, Davies PM (2010) Global threats to human water security and river biodiversity. Nature 467:555-561

Zhang J, Liu CL (2000) Riverine composition and estuarine geochemistry of particulate metals in China-weathering features, anthropogenic impact and chemical fluxes. Estuar Coast Shelf Sci 54:1051-1070 